\title{
Effect of Socio-Economic Attributes on Resident's Satisfaction in Low-Density Area of Bauchi Metropolis
}

\section{Muhammad Umar ${ }^{1}$, Oyediran Olufemi Oyeleke ${ }^{2}$, Moses Adegbile Adeleke ${ }^{3}$ Sulaiman Adekunle Ojeniyi ${ }^{4}$}

\author{
${ }^{1}$ Abubakar Tafawa Balewa University \\ Dass road, P. M. B. 0248, Bauchi, 740272, Nigeria \\ 2 Federal Polytechnic Nasarawa \\ P. M. B. 01, Nasarawa, Nigeria \\ 3 The Oke-Ogun Polytechnic, Saki \\ P. M. B. 21, Saki, Nigeria \\ ${ }^{4}$ Ecole Superieure Sainte Felicite University \\ 03 BP, 4050, Cotonou, Benin Republic
}

DOI: $10.22178 /$ pos. $71-9$

Abstract. This study examined the effect of socio-economic attributes of residents on housing satisfaction in the Bauchi metropolis to reveal ways to improve households' housing situation in the Bauchi metropolis. The study adopted a quantitative approach. The questionnaire was designed and administered to 380 House Hold Heads with 258 retrieved. Households were surveyed employing stratified random sampling to generate data on the households' socio-economic attributes and housing satisfaction. Data collected were subjected to descriptive statistics (Mean score and frequency table) and multiple regression through the use of SPSS to examine the effect of variables. The study revealed that most households have means of earning income and that household size is large. Households in the low-density area have moderate satisfaction with their housing condition. The study demonstrated a significant effect of socio-economic attributes on housing conditions and satisfaction in the study area. As a matter of urgency, it was recommended that the government provide the lacking social amenities, renovate the deteriorating ones, and enforce development control standards.

(C) 2021 The Authors. This article is licensed under a Creative Commons Attribution 4.0 License @) (-)

Keywords: socio-economic characteristics; housing; housing satisfaction; Bauchi; Nigeria.

\section{INTRODUCTION}

Socio-economic characteristic defines family's position, rank, class, status or economic position in a community [3]. Socio-economic attributes differ from one household to the other, and it provides a social picture at a glance, such as occupation, income and education. In addition, it is based upon the concepts of allocating limited resources to various activities related to protection and conservation [1].

The quality of life is closely associated with housing. Housing is committed by other factors such as income, employment, education, work-life balance, life satisfaction, and society's perceived quality [9]. Housing is the sole pillar of individual satisfaction and has been considered "to be the determinant of the quality of life" [8].

Housing satisfaction thus is determined by residents' perceptions of their neighbourhood and living conditions. This suggests a low level of dissatisfaction and a high degree of agreement between desired and actual conditions and the satisfaction of residents' everyday housing needs. On the contrary, incongruence between their actual and desired housing conditions may lead to dissatisfaction [5]. However, there is a propensity for low-income families to be satisfied with housing with more deficit than middle-income families. This is because low-income acts as a constraint in 
that low-income families cannot obtain non-deficit housing [4].

Furthermore, Bauchi observed that an individual's socio-economic characteristics influence his earnings, influencing his housing satisfaction. Hence the practical gap is acknowledged. Against this backdrop, this study examined the effect of individual-based socio-economic characteristics on housing satisfaction in the Bauchi metropolis and ascertained how households' socio-economic characteristics affected their housing satisfaction.

This study aims to determine the effect of socioeconomic attributes on resident's satisfaction in the low-density area of the Bauchi metropolis, revealing the significant relationship of the effect of socio-economic attributes condition on resident satisfaction.

\section{Objectives:}

1. To identify the socio-economic characteristics of residents in the Bauchi metropolis.

2. To examine the level of resident's satisfaction in the study area.

3. To assess the effect of socio-economic attributes on residents' satisfaction in the study area.

\section{Methodology}

The research methodology adopted is quantitative. The questionnaire was developed and administered to the respondents. A total of one hundred and twenty-six (126) copies of the questionnaires were administered in which Out of the 126 questionnaires administered, 94 valid copies were filled and retrieved. The sample size selection is somewhat similar to those used by other social science researchers (such as [2, 6]) in Nigeria as the basis for obtaining the sample size. Sixty-three households are sampled within each of these residential neighbourhoods making a total number of 126 households. The old and new GRA was chosen from the low-density residential areas. The sampling method adopted was the stratified random sampling method, which is the most fundamental method and gives every subject in a population an equal chance of being selected. After the considerable collection of data, the method of data analysis employed to analyse the data gathered from the field was descriptive, mean ranking and multiple regression using SPSS Version 22.

\section{RESULTS AND DISCUSSIONS}

Table 1 revealed the socio-economic attributes of the respondent. Again, males were the predominant respondents in the study area. Similarly, the research has found that people within the age less than 30 years accounted for (53.19\%) of the total population. Also, the survey indicates that the majority of the respondents were married (67.02\%).

Table1 - Demographic Data of the Respondents

\begin{tabular}{|c|c|c|}
\hline & & $\%$ \\
\hline & Sex & \\
\hline Male & 75 & 80.2 \\
\hline \multirow[t]{2}{*}{ Female } & 19 & 19.8 \\
\hline & Age & \\
\hline Less than30 years & 50 & 53.19 \\
\hline between $31-40$ years & 20 & 21.28 \\
\hline between $41-50$ years & 18 & 19.15 \\
\hline \multirow[t]{2}{*}{ above 50 years } & 6 & 6.38 \\
\hline & Marital status & \\
\hline Single & 31 & 32.98 \\
\hline \multirow[t]{2}{*}{ Married } & 63 & 67.02 \\
\hline & Education & \\
\hline Primary school & 14 & 14.90 \\
\hline O level & 29 & 30.85 \\
\hline OND/NCE & 32 & 34.04 \\
\hline HND & 12 & 12.77 \\
\hline BSC & 5 & 5.32 \\
\hline MSC & 1 & 1.06 \\
\hline \multirow[t]{2}{*}{ PHD } & 1 & 1.06 \\
\hline & Occupation & \\
\hline Farming & 17 & 18.09 \\
\hline Civil Servant & 29 & 30.85 \\
\hline Business & 9 & 9.57 \\
\hline Retired & 14 & 14.89 \\
\hline \multirow[t]{2}{*}{ Artisan } & 25 & 26.60 \\
\hline & Religion & \\
\hline Islam & 82 & 87.23 \\
\hline \multirow[t]{2}{*}{ Christianity } & 12 & 12.77 \\
\hline & Income & \\
\hline Less than \#30,000 & 27 & 28.72 \\
\hline$\# 31,000-\# 60,0000$ & 39 & 41.49 \\
\hline \#61,0000-\#91,000 & 18 & 19.15 \\
\hline \multirow[t]{2}{*}{ \#91,000 and above } & 10 & 10.64 \\
\hline & Household Size & \\
\hline $6-10$ & 51 & 54.26 \\
\hline $11-15$ & 23 & 24.47 \\
\hline $16-20$ & 14 & 14.89 \\
\hline \multirow[t]{2}{*}{21 persons and above } & 6 & 6.38 \\
\hline & Tribe & \\
\hline Hausa & 78 & 82.98 \\
\hline Yoruba & 10 & 10.64 \\
\hline Igbo & 6 & 6.38 \\
\hline
\end{tabular}


The result of the households' occupation shows that majority of the respondents are civil servants. At the same time, $69.15 \%$ of the entire respondent are people who are retirees, students, craftsmen and artisans in the whole study area. This indicates that most of the respondents in the study area have the means to derive some income and are NCE holders.

Also, analysis of households' income indicates that most participants have an income of N31,000- N60,000. Furthermore, the majority of the residents practice Islam as a faith. This corresponds with [00] findings, which stated that most Bauchi metropolitan area residents practise the Islamic religion. Also, the study reveals that the majority 51 (54.26\%) of respondents have 6-10 members within the fold of their households. Finally, the principal tribe are the Hausas which also conforms with the study by [6].

Table 2 - Ranking Residents Satisfaction

\begin{tabular}{|l|r|r|r|}
\hline \multicolumn{1}{|c|}{$\begin{array}{c}\text { Physical } \\
\text { Characteristics }\end{array}$} & Mean & $\begin{array}{c}\text { Std. } \\
\text { Deviation }\end{array}$ & Ranking \\
\hline $\begin{array}{l}\text { Toilet and Bathroom } \\
\text { Facilities }\end{array}$ & 3.6809 & .88248 & 1 \\
\hline Rendered and painted & 3.5745 & 1.20473 & 2 \\
\hline Tiles & 3.5426 & 1.48588 & 3 \\
\hline $\begin{array}{l}\text { Well Equipped } \\
\text { Kitchen }\end{array}$ & 3.5000 & 1.41231 & 4 \\
\hline No finishing at all & 3.3617 & 1.12500 & 5 \\
\hline $\begin{array}{l}\text { Electricity from public } \\
\text { main }\end{array}$ & 3.3404 & 1.21419 & 6 \\
\hline Generator & 3.2872 & 1.20592 & 7 \\
\hline $\begin{array}{l}\text { Kitchen without } \\
\text { modern Facilities }\end{array}$ & 3.1596 & 1.24696 & 8 \\
\hline Sand Crete & 3.1489 & 1.48075 & 9 \\
\hline Pit Toilet & 3.0957 & 1.38400 & 10 \\
\hline Candle & 3.0319 & .96667 & 11 \\
\hline $\begin{array}{l}\text { Waste Disposal } \\
\text { Facilities }\end{array}$ & 3.0213 & 1.42918 & 12 \\
\hline $\begin{array}{l}\text { Rendered without } \\
\text { Paint }\end{array}$ & 2.9787 & 1.42164 & 13 \\
\hline Burnt Bricks & 2.9574 & 1.45849 & 14 \\
\hline Bore hole & 2.8723 & 1.45346 & 15 \\
\hline Aluminium & 2.6809 & 1.71152 & 16 \\
\hline Cemented & 2.6596 & 1.50664 & 17 \\
\hline Well & 2.4681 & 1.52475 & 18 \\
\hline Terrazo & 2.2234 & 1.43050 & 21 \\
\hline Clay/Mud Block & 1.9894 & 1.30750 & 22 \\
\hline Corrugated Iron Sheet & 1.29484 & 23 \\
\hline Kerosene Lamp & 1.20952 & 24 \\
\hline Asbestos & & & 20 \\
\hline Pipe Borne & & & \\
\hline
\end{tabular}

Table 2 above revealed the satisfaction of households in the low-density area of Bauchi Metropolis. The household expressed their opinion that their satisfaction is moderate. The Toilet and Bathroom Facilities has (M=3.68, $S=1.88)$ and was ranked 1st. The Rendered and Painted has ( $\mathrm{S}=3.57, \mathrm{~S}=1.20$ ) and was ranked 2nd. The Tiles has $(M=3.54, S=1.48)$ and was ranked 3rd.their satisfaction with Well Equipped Kitchen was also moderate with $(\mathrm{M}=3.50, \mathrm{~S}=1.41)$ and was ranked 4th. They were dissatisfied with their Kerosene was ranked 22nd with $(\mathrm{M}=1.98, \mathrm{~S}=1.30)$. The Asbestos has $(\mathrm{S}=1.82,1.29)$ and was ranked 23rd, Pipe-borne has $(\mathrm{M}=1.98, \mathrm{~S}=1.23)$ and was ranked 24th. Therefore, the table indicates that the majority of the household have reasonable satisfaction in their neighbourhood characteristics. But they are dissatisfied with a few of their neighbourhood characteristics.

Table 3 - Model Summary and ANOVA

\begin{tabular}{|l|c|c|c|c|c|c|}
\hline Model & $\mathrm{R}$ & $\mathrm{R}^{2}$ & $\begin{array}{c}\text { Adjusted } \\
\mathrm{R}^{2}\end{array}$ & $\begin{array}{c}\text { Std. Error } \\
\text { of the } \\
\text { Estimate }\end{array}$ & $\mathrm{F}$ & Sig. \\
\hline 1 & $.387 \mathrm{a}$ & .150 & .101 & .45754 & 3.052 & $.000 \mathrm{~b}$ \\
\hline
\end{tabular}

Table 3 shows the regression model summary and the ANOVA result. The model produced an overall $\mathrm{R}$-value of 0.387 and $\mathrm{R}^{2}$ value of 0.101 with F-statistics of 3.052, which shows a highly significant value of .000 which means $p$ is less than 0.05 . The model as a whole predicts about $38.7 \%$ of the variance in housing satisfaction. In other words, about $15 \%$ of the changes in housing satisfaction can be explained by changes in socio-economic attributes. The table presents the goodness fittest of the model, which shows that the model is fitted and suitable for the analysis as it produced a highly significant p-value of .000.

Table 4 is the coefficient table that shows the significant relationship between socio-economic attributes and housing satisfaction. Gender and Farming were the socio-economic attributes that significantly impact housing satisfaction as they have a Beta value of -.210 and .270 with a p-value of both .001 and .000, respectively. While single, divorced, widow, Yoruba, Jarawa Gyarawa Business, Occupation, Age, Income, Education, and Family have a beta value of .007, 051, -161, .068, $.032,-.133,-.052, .083, .021$ and .025 respectively were found to have a less significant impact. 
Table 4 - Coefficient Table

\begin{tabular}{|l|c|c|c|c|c|}
\hline \multirow{2}{*}{ Model } & \multicolumn{2}{|c|}{ Unstandardised Coefficients } & Standardised Coefficients & \multirow{2}{*}{ T } & \multirow{2}{*}{ Sig. } \\
\cline { 2 - 4 } & $\mathrm{B}$ & Std. Error & Beta & 16.736 & .000 \\
\hline Constant & 2.970 & .177 & & -3.251 & .001 \\
\hline Gender & -.254 & .078 & -.210 & .095 & .924 \\
\hline Single & .007 & .074 & .007 & .749 & .455 \\
\hline Divorced & .134 & .179 & .051 & -2.444 & .015 \\
\hline Widow & -.563 & .230 & -.161 & 1.130 & .260 \\
\hline Yoruba & .133 & .118 & .068 & .449 & .654 \\
\hline Business & .034 & .076 & .032 & 4.141 & .000 \\
\hline Farming & .432 & .104 & .270 & -1.826 & .069 \\
\hline Occupation & -.159 & .087 & -.133 & -.689 & .491 \\
\hline Age &. .041 & .059 & -.052 & 1.300 & .195 \\
\hline Income & .040 & .031 & .083 & .320 & .749 \\
\hline Education & .009 & .029 & .021 & .394 & .694 \\
\hline Family & .012 & .029 & .025 & & \\
\hline
\end{tabular}

So, this concludes that Gender and Farming as a form of occupation were the only socio-economic attributes that significantly affect housing satisfaction.

\section{CONCLUSIONS}

From the analysis conducted so far, it is evidenced that socio-economic attributes affect neighbourhood satisfaction. The analysis is based on mean scoring and multiple regression, revealing that most households are pretty satisfied with their neighbourhood characteristics. Furthermore, the study revealed that out of the socio-economic attributes, gender and Farming as a form of occupation were the only socio-economic attributes that significantly affect housing satisfaction. Therefore, the generation of employment opportunities, otherwise known as economic revitalisation, is highly needed in the area.

In view that socio-economic characteristics influence resident satisfaction, the government should provide lacking social amenities, rehabilitate any that are deteriorating, and enforce development control standards to improve resident satisfaction in the study area. In addition, organised private sectors should establish institutions to create employment opportunities and quality education for residents of the study area to improve their financial status.

\section{REFERENCES}

1. Agrawal, A., \& Ostrom, E. (2001). Collective Action, Property Rights, and Decentralization in Resource Use in India and Nepal. Politics \& Society, 29(4), 485-514. doi: 10.1177/0032329201029004002

2. Bello, A., \& Egresi, I. (2017). Housing Conditions in Kano, Nigeria: a Qualitative assessment of adequacy. Analele Universitatii din Oradea, Seria Geografie, 2, 205-229.

3. Galobardes, B., Shaw, M., Lawlor, D. A., Lynch, J. W., \& Davey Smith, G. (2006). Indicators of socioeconomic position (part 2). Journal of epidemiology and community health, 60(2), 95-101. doi: 10.1136/jech.2004.028092

4. Hashim, H. (2017). Linking the past to the present: housing history and the sense of home in temporary public rental housing in Sarawak (Doctoral dissertation). Retrieved from https://minervaaccess.unimelb.edu.au/handle/11343/194654

5. Mohit, M. A., Ibrahim, M., \& Rashid, Y. R. (2010). Assessment of residential satisfaction in newly designed public low-cost housing in Kuala Lumpur, Malaysia. Habitat International, 34(1), 1827. doi: 10.1016/j.habitatint.2009.04.002 
6. Muhammad, M. (2015). Framework of the existing patterns of residential segregation and housing quality in Nigeria (Doctoral thesis), Universiti Tun Hussein Malaysia. Retrieved from https://core.ac.uk/download/pdf/83541295.pdf

7. Muhammad, M. S., Kasim, R., \& Martin, D. (2015). An Evaluation of Factors Influencing Residential Segregation in Selected Areas of Bauchi Metropolis, Northern Nigeria. Mediterranean Journal of Social Sciences, 2. doi: 10.5901/mjss.2015.v6n2s1p127

8. Rašticová, M., \& Kolářová, I. (2015). Myths about ageing population. In Innovation Vision 2020: from Regional Development Sustainability to Global Economic Growth. Amsterdam: International Business Information Management Association (IBIMA).

9. Rašticová, M., Birčiaková, N., Kolářová, I., \& Rampulová, K. (2016). Seniors' Life Satisfaction in Regions of the Czech Republic. Lecture Notes of the Institute for Computer Sciences, Social Informatics and Telecommunications Engineering, 898-908. doi: 10.1007/978-3-319-336817_80 